\title{
Laboratory and Field Evidence for a Vadose Origin of Foibe (Domepits)
}

By Max W. Reams ${ }^{1}$ )

With 6 figures in the text

\section{Introduction}

Foiba (plural, foibe) is a term applied to natural, vertical wells and similar nearly cylindrical cavities in the northeastern Italian karst region, the Carso (Il Novissimo Melzi, Scientifico, 1954, p. 505; Instituto Geografico Militare, 1924, 1930; Luciano B. Ronca, personal communication, September, 1962). Foiba is defined in the present paper as a cavity in relatively soluble rock which is natural, solutional, tends toward a cylindrical shape, and possesses walls normally approaching verticality. This definition is used because it is descriptive but possesses genetic connotations sufficient to associate it with a karst region and to further distinguish it from some features in caves formed under phreatic conditions or by collapse. Foibe exist with or without direct openings to the surface.

Foibe have been reported from the various karst regions of Europe, Central America, and the United States. The names applied to these cavities vary from region to region, e.g., trojes and tecontles in Mexico (McAllister and Hernandez, 1945, p. 60-62, pl. 12, 20) and domes, pits, dome-pits, domepits, pitdomes, vertical shafts, chimneys, natural wells, and wells in the United States (Davies, 1950; Davis, 1930; Merrill, 1960; Pohl, 1955; Watson, in preparation). Some of the "gills" in the karst of the Carboniferous of England may be foibe (Charles S.Hutchison, personal communication, October, 1963) and the karstovyi shakhta ("karst mines" or karst shafts) of the Crimea may also fit the above definition (Ivanov and Dublyansky, 1959). For the sake of uniformity, it is suggested that foiba become the accepted scientific name applied to all such related cavities.

The only area in the United States where foibe have been well studied is the central Kentucky karst region (Pohl, 1955; Merrill, 1960). The foibe in this area range in height up to $73 \mathrm{~m}$. and are

\footnotetext{
1) Department of Geology, University of Kansas, Lawrence, Kansas, USA. Present address: Dept. of Earth Sciences, Washington University, St. Louis, Missouri, USA.
} 
generally restricted to the edges of flat-topped ridges capped by sandstone and shale and underlain by several hundred meters of Mississippian (Lower Carboniferous) limestones. The walls of these foibe possess vertical lapies, and fossils stand in relief. Water from the surface is supplied to these cavities from sinkholes, ravines, etc.

Most workers agree that Kentucky foibe are the product of vadose solution along vertical fractures or intersecting fractures. However, there is considerable discussion concerning the exact way this enlargement takes place. Two basic views are currently under consideration and a third, proposed by the author, is elucidated:

1. The upward extension theory. This view holds that foibe form near the water table and expand upward and laterally, with little downward expansion (Brucker, 1960, and in preparation).

2. The downward extension theory. This view is based on the concept that foibe are initiated above the water table and expand downward and laterally with little upward development (Merrill, 1960; Pohl, 1955).

3. The lateral extension theory. This view, proposed by the author (Reams, $1963 \mathrm{a} ; 1963 \mathrm{~b}$ ), postulates that foibe develop by lateral expansion of joints, beneath less soluble layers, contemporaneously from near the surface down to the water table.

The purpose of this paper is to present a body of evidence drawn from laboratory model studies, field observations, and water analyses in support of the lateral extension theory.

\section{Experimental Evidence}

Previous experimental work concerning foibe was done by Saint Vincent (1819) with water directed onto a sugar cube, and by Meunier (1875, 1899) who used hydrochloric acid directed onto limestone blocks. Meunier's method was incompletely described and his results are difficult to interpret. When experimenting with solutional forms, the detailed methods used will greatly influence the shape of the cavity produced. For this reason, considerable care must be taken when sctting up experiments, and in recording data as the experiments proceed. These two points must be considered when interpretations are made. Similarities between the model and the natural object mean little unless the environment which produced the model approached the natural environment.

The limestone chosen for most of the experiments in the present study was the Leavenworth Member of the Oread Formation of Pennsylvanian (Upper Carboniferous) age. This unit was chosen because it is 
dense, massive, and readily accessible. The insoluble residue content is approximately 10.5 per cent, sufficiently pure for the purpose. The acid used was usually hydrochloric diluted with distilled water to a ratio of $1: 250$ by volume. Many concentrations of acid were tried and it was found that 1:250 was nearly ideal for the size of blocks used and the time desired for the experiments to reach completion.

The limestone was sawed into blocks of a convenient size, usually $2 \times 3 \times 15 \mathrm{~cm}$. The sawed block was clamped firmly to a stand so that the flat, front face was normally vertical. This face simulated a joint plane. The dilute acid was siphoned from a container through Tygon tubing to a glass tube where the acid dripped or flowed onto the edge of the limestone block and down the front face. A clamp controlled the rate of flow. The base of the block was immersed in a bath of circulating tap water to simulate a water table. Another limestone block was submerged in the water to help negate the excess acid and prevent side effects on the base of the block being treated (Fig. 1). The experiments usually lasted from about one day to one week of dissolving time. The rates of flow of dilute acid ranged from about two liters per day to one liter per hour.

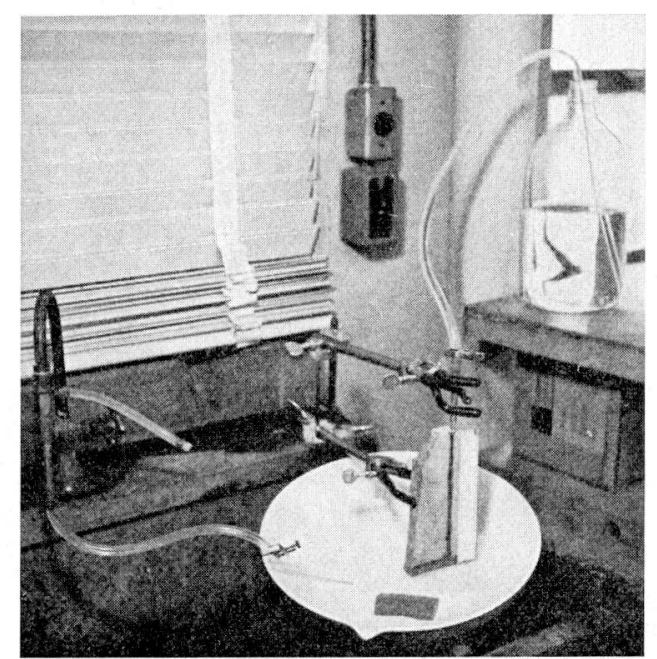

Fig. 1. Laboratory apparatus used in simulating foibe (see text for explanation).

Many variations from the above method were employed, e.g., vertical grooves were cut into the front faces to simulate intersecting fractures, 
but the resulting cavities were nearly identical to models starting with ungrooved front faces.

The main objective of the experiments was to find the reason for the remarkably vertical walls of foibe studied in the United States. To test the prevailing thought that a thin film of water descending foiba walls was the active agent, the effectiveness of such a film of water to dissolve vertical walls was determined. A flattened glass tube was used to spread a film of acid over a wide area of a block. No water bath was used in this instance. As the limestone was dissolved, the glass tube was moved to keep the liquid flowing constantly over the face of the block. Dripping the solution onto the face was avoided as much as possible. The slowly moving film of acid dissolved the most susceptible areas and, consequently, remnant, jagged ridges stood in relief. There is a very close resemblance between this model and solutional, jagged ridges formed in caves by similar processes.

In the early stages of development in the above model, it was evident that more rock was being dissolved from the upper part of the cavity than the lower part (Fig. 2). The wall of the final cavity deviated from the original vertical by several degrees.

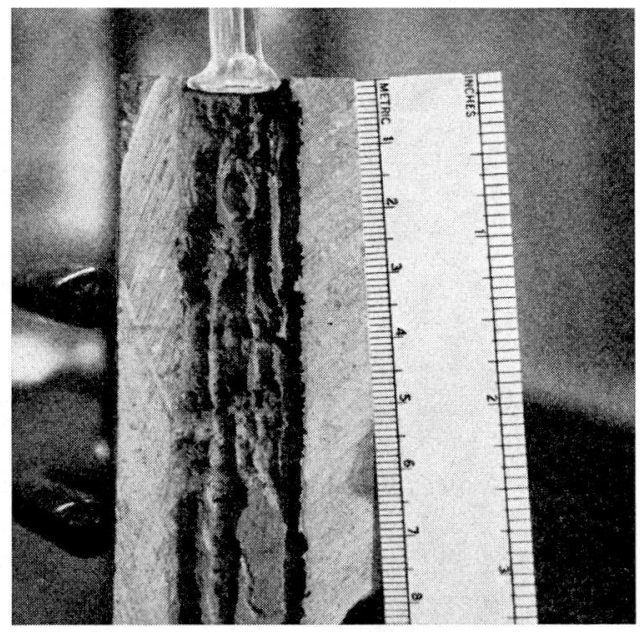

Fig. 2. Experiment testing the effect of a film of solvent on a smooth vertical face. Note the remnant, jagged ridges.

To further test the process of solution by a solvent film, two grooved blocks were clamped with grooved faces together and placed in a vertical position. A ring of vaseline was formed on the top surface of the joined blocks to direct acid into the prepared hole. The resulting 
cavity was widest at the top and decreased in size toward the bottom. The geometry of this cavity strongly resembled "cutters." Cutters are solutional sinkholes without surface expression which are formed by enlargement of joints (Howard, 1963).

A thin solvent film of acid produces a cavity shaped like a sinkhole or a model with slanting walls. Therefore, some other agent must be responsible for the nearly vertical walls of foibe. To see if a less soluble layer could control water flow along a fracture, a glass slide, simulating a layer of chert or shale, was placed on the top surface of the model, flush with the limestone face. Acid was allowed to fall, drop by drop, onto the edge of the flat slide while the acid source remained stationary. The slide broke up the individual drops and caused the acid to reach the face of the limestone in somewhat dispersed droplets. After contact, the acid ran down the face of the block in a thin stream. A half-dome shape developed just under the slide. Ireland (1955) has shown the importance of surface tension in similar geologic situations. The etched wall which developed below the slide became a nearly vertical face.

At the beginning of the above experiment, the area just below the slide was the most vigorously attacked because the drop first touched soluble material there. The solution was least saturated and the velocity was highest at that point. Kaye (1957) and Weyl (1958) have shown that the rate of solution of calcium carbonate increases linearly with increasing velocity. As the upper area was eroded back it received less and less solvent and the area farther below was the most vigorously attacked. As this lower area was eroded back, it too received less liquid and the area below it in turn was the most vigorously attacked, etc. The end result was a vertical wall.

Vertical walls may also be produced in laboratory models by removing the glass slide from the top surface and clamping the glass tube in a stationary position throughout the experiment. The broader part of the cavity is at the top of the model during the initial stages. As the experiment proceeds, the upper area does not increase in size because the acid falls to lower and lower levels before encountering the limestone. The end result is again a vertical wall.

The same effects and result are obtained if the block is tilted to simulate dipping beds (Fig. 3). Lowering of the most active area of solution gives the illusion of a lowering floor level. A better idea of the process is illustrated by the cross-section of the block model in Figure 4.

From the above experiments it becomes clear that water in free fall (dripping, etc.) is necessary for the development of vertical-walled 
cavities in relatively soluble rocks. It seems that dripping water can be a permanent feature in natural cavities only if a less soluble layer is present to restrict flow. The walls of a cavity developed below a less soluble layer are probably not vertical during incipient stages but are tilted at a slight angle from the vertical, thus forming a very steep funnel reaching to the water table. This concept is consistent with the findings of Howard (1963) concerning cavities formed beneath less soluble layers. If the rock sequence is interrupted by other less soluble layers, temporary foiba floors will be formed. Otherwise, the floors only form near the water table.

Shortly after inception, the walls of the solutional cavity should approach verticality quite rapidly after dripping water becomes dominant, and maintain this angle during most of the cavity's life. Dripping water will be the controlling factor as far as the wall angle is concerned. However, differential solution produces irregularities in the wall.

No definite limit can be placed on the required diameter of a cavity before vertical walls will become dominant because of the variability of quantity and quality of water entering the cavity and variations in lithology. However, field evidence indicates that less than a meter would be the correct order of magnitude, provided a cavity does not

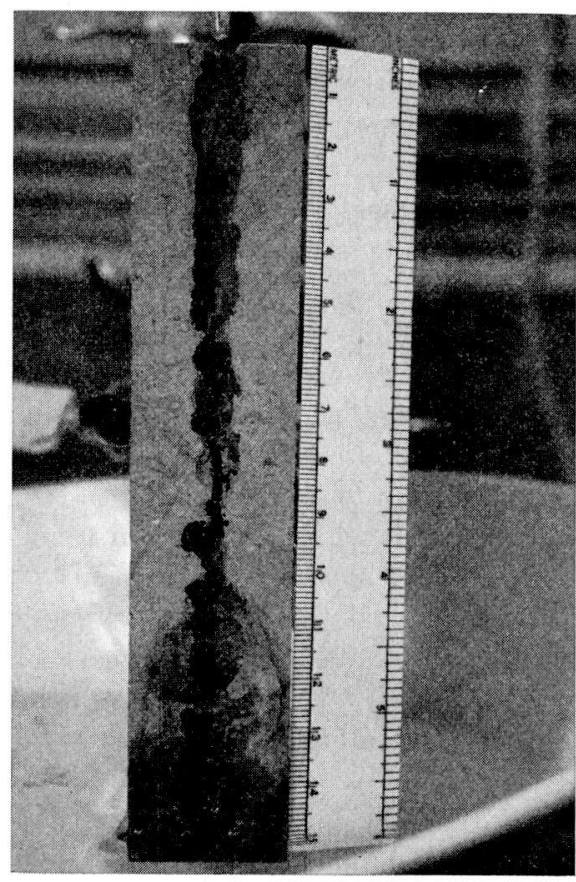
become clogged with debris introduced from above.

Fig. 3. Experiment testing the effectiveness of a solvent dripping onto a tilted surface. Note that the cavity stops at the water level. Remnant rock arches conceal part of the cavity. 


\section{Water-Sample Evidence}

Water-sample data from foibe in central Kentucky and central and southern Missouri provide interesting contrasts in water chemistry (Table). However, the variations between the two regions are not as pronounced as might appear on cursory examination. Annual variations are very important in the interpretation of cave-water chemistry, as suggested by Moore (1962). A detailed study of annual fluctuations (Reams and Vineyard, in preparation) will aid in the clarification of the effects of climate, microbial activity, and temperature on cave-water chemistry. Holland, et al. (1964) have discussed the general chemistry of water in caves.

The Kentucky samples were taken during a relatively moist summer. Such samples were of lower concentration with respect to the principal ions of cave-waters than were samples taken in Missouri foibe. The principal ions in karst waters are: calcium $\left(\mathrm{Ca}^{++}\right)$, magnesium $\left(\mathrm{Mg}^{++}\right)$, and bicarbonate $\left(\mathrm{HCO}_{3}{ }^{-}\right)$. The Missouri samples represent two climatic opposites: cold, mid-winter weather and extreme drought during warm, late summer. The contrasts between the Missouri samples are striking. The concentrations of the principal ions are much higher in the late summer samples than the mid-winter samples.

During hot, dry conditions, the only sources of water for foibe, which reach close to the surface in Missouri and Kentucky, would be soil moisture brought down by gravity and water from springs rising from higher units. The latter case is very important in Kentucky and may be in Missouri (Jerry D.Vineyard, personal communication, December, 1963).

Water brought down as soil moisture under drought conditions would be extremely high in carbonic acid $\left(\mathrm{H}_{2} \mathrm{CO}_{3}\right)$ and its ions,

Fig. 4. Cross-section diagram of a vertical experimental model. The dotted line outlines the cavity. The " $X$ " marks the point where water presently strikes the limestone. The water level is marked by the dashed line.

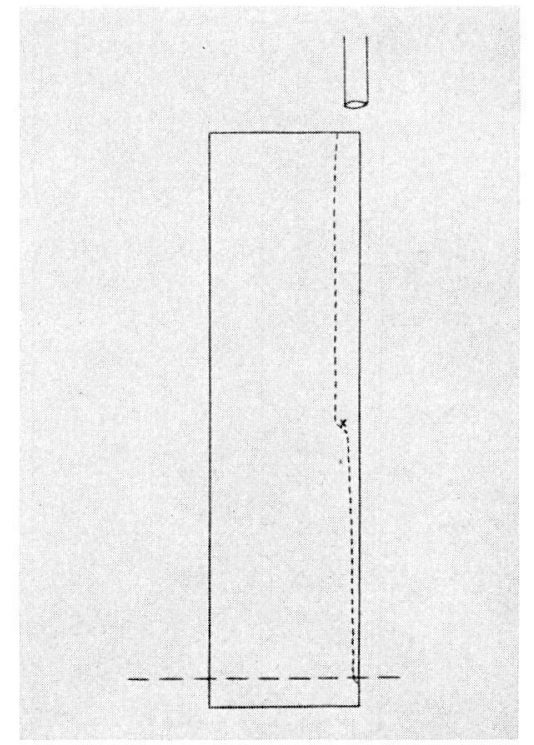


Table. Analytical water sample data expressed in parts per million and temperatu are fro

\begin{tabular}{|c|c|c|c|c|c|c|c|c|c|}
\hline $\begin{array}{l}\text { Sample } \\
\text { Number }\end{array}$ & $\begin{array}{l}\text { Tem- } \\
\text { per- } \\
\text { ature }\end{array}$ & $\begin{array}{l}\mathrm{pH} \\
\text { (lab) }\end{array}$ & $\begin{array}{l}\mathrm{Ca}^{+2} \\
\pm 3 \%\end{array}$ & $\begin{array}{l}\mathrm{Mg}^{+2} \\
\pm 10 \%\end{array}$ & $\begin{array}{l}\mathrm{Na}^{+} \\
\pm .2\end{array}$ & $\begin{array}{l}\mathrm{K}^{+} \\
\pm .2\end{array}$ & $\begin{array}{c}\mathrm{Sr}^{+2} \\
\pm 10 \%\end{array}$ & $\begin{array}{c}\mathrm{HCO}_{3}- \\
\pm 1 \%\end{array}$ & $\begin{array}{l}\mathrm{SO}_{4} \\
\pm .8\end{array}$ \\
\hline 1 & 11.5 & 7.55 & 31.6 & 9.6 & 2.3 & 1.8 & & 105 & 9.9 \\
\hline 2 & 12.5 & 7.73 & 29.0 & 6.7 & 1.2 & 1.3 & & 103 & 4.1 \\
\hline 3 & 12.5 & 7.64 & 28.7 & 9.9 & 1.4 & 1.4 & & 103 & 6.4 \\
\hline 5 & 10.5 & 7.70 & 30.3 & 5.8 & 1.5 & 1.0 & & 102 & 7.8 \\
\hline 6 & 10.5 & 7.52 & 35.1 & 4.2 & 1.6 & 1.0 & & 114 & 8.4 \\
\hline 4 & 10.5 & 7.63 & 31.2 & 7.0 & 1.5 & 0.9 & & 104 & 8.6 \\
\hline 7 & 10.5 & 7.43 & 33.8 & 5.1 & 1.5 & 1.0 & & 113 & 10.2 \\
\hline 8 & 13.0 & 7.55 & 31.9 & 3.8 & 1.5 & 0.9 & & 104 & 6.8 \\
\hline 9 & 11.5 & 7.60 & 39.6 & 5.8 & 0.7 & 0.5 & & 132 & 4.0 \\
\hline 10 & 11.5 & 7.70 & 40.3 & 5.1 & 0.7 & 0.5 & & 136 & 5.2 \\
\hline 11 & 11.0 & 7.66 & 40.3 & 5.4 & 0.7 & 0.5 & & 136 & 6.1 \\
\hline 12 & 10.5 & 7.61 & 55.4 & 6.1 & 0.75 & 0.8 & & 139 & 27.4 \\
\hline 15 & 9.7 & 7.85 & 29.95 & 8.3 & 1.0 & 1.1 & & 103 & 7.8 \\
\hline 14 & 11.0 & 7.63 & 37.4 & 7.4 & 1.5 & 1.1 & & 108 & 19.5 \\
\hline 13 & 10.0 & 7.60 & 35.4 & 7.0 & 1.4 & 1.1 & & 105 & 16.8 \\
\hline 16 & 10.0 & 7.62 & 37.4 & 7.7 & 1.5 & 1.2 & & 111.5 & 18.2 \\
\hline 17 & 10.5 & 7.61 & 37.0 & 7.7 & 1.3 & 1.1 & & 111 & 19.9 \\
\hline 18 & 12.2 & 7.78 & 33.2 & 8.0 & 1.2 & 0.9 & & 113 & 9.4 \\
\hline 21 & 12.0 & 7.76 & 42.5 & 3.8 & 3.3 & 2.0 & & 110 & 21.9 \\
\hline 20 & 12.0 & 7.80 & 41.2 & 4.5 & 3.2 & 1.9 & & 112 & 22.4 \\
\hline 19 & 12.0 & 7.76 & 40.9 & 5.1 & 3.3 & 2.2 & & 111 & 21.7 \\
\hline 22 & 12.0 & 7.73 & 36.1 & 4.2 & 1.3 & 1.0 & & 104 & 13.3 \\
\hline 23 & 12.5 & 7.78 & 31.2 & 4.8 & 1.3 & 0.85 & & 111 & 5.2 \\
\hline 24 & 12.5 & 7.98 & 30.3 & 5.4 & 1.3 & 0.8 & & 104 & 4.2 \\
\hline 27 & 11.2 & 7.73 & 30.9 & 4.5 & 0.9 & 0.8 & & 102 & 4.4 \\
\hline 26 & 11.2 & 7.80 & 32.5 & 3.2 & 0.7 & 0.6 & & 103 & 2.2 \\
\hline 25 & 11.2 & 7.79 & 32.85 & 2.6 & 0.8 & 0.7 & & 102.5 & 2.6 \\
\hline \multirow[t]{12}{*}{28} & 14.0 & 7.60 & 27.7 & 1.6 & 0.7 & 0.5 & & 88.6 & 0.0 \\
\hline & & & 26 & 16 & 2.25 & 0.5 & 0 & 165 & 8 \\
\hline & 5.5 & & 26 & 14 & 2.50 & 1.0 & $3(?)$ & 164 & 8 \\
\hline & 14.5 & & 44 & 47 & 0.5 & 0.5 & 0 & 328 & 17 \\
\hline & 13.0 & & 49 & 20 & 15.0 & 1.0 & 0 & 162 & 14 \\
\hline & 13.0 & & 39 & 3.5 & 20 & 1.0 & 0 & 156 & 13 \\
\hline & 15.0 & 7.63 & & & & & & 313 & \\
\hline & 12.0 & 7.78 & & & & & & 233 & \\
\hline & 12.0 & 7.78 & 50 & 32 & & & & 301 & \\
\hline & 12.0 & 7.72 & 94 & 70 & & & & 622 & \\
\hline & 12.0 & 7.65 & 37 & 31 & & & & 264 & \\
\hline & 12.0 & 7.92 & & & & & & 518 & \\
\hline
\end{tabular}


degrees centigrade. Samples 1-28 are from central Kentucky and the remainder issouri

\begin{tabular}{|c|c|c|c|c|}
\hline $\begin{array}{l}\mathrm{Cl}^{-} \\
\pm .2\end{array}$ & $\begin{array}{l}\text { Total } \\
\text { Solids } \\
\pm 8 \% \\
\end{array}$ & Date & Cave & Location \\
\hline$<1.8$ & 135 & $7 / 11 / 62$ & Mammoth & Roosevelt Dome-pool \\
\hline$<0.4$ & 110 & $7 / 12 / 62$ & Mammoth & $\begin{array}{c}\text { Foiba (?) feeding Devil's Cooling } \\
\text { Tub }\end{array}$ \\
\hline 1.0 & 109 & $7 / 12 / 62$ & Mammoth & Devil's Cooling Tub-pool \\
\hline$<0.4$ & 124 & $7 / 12 / 62$ & Mammoth & Annetta's Dome- $5.5 \mathrm{~m}$. above pool \\
\hline 0.96 & 122 & $7 / 12 / 62$ & Mammoth & Annetta's Dome-1.3 m. above pool \\
\hline 0.96 & 118 & $7 / 12 / 62$ & Mammoth & Annetta's Dome-pool \\
\hline$<0.4$ & 130 & $7 / 12 / 62$ & Mammoth & Lee's Cistern-pool \\
\hline$\sim 0.4$ & 112 & $7 / 13 / 62$ & James & Miniature Foiba-pool \\
\hline$<0.4$ & 138 & $7 / 16 / 62$ & Long & Foiba drain \\
\hline$\sim 0.4$ & 134 & $7 / 16 / 62$ & Long & $3.7 \mathrm{~m}$. below and laterally from $\# 9$ \\
\hline$<0.4$ & 131 & $7 / 16 / 62$ & Long & $0.6 \mathrm{~m}$. below \# 10 \\
\hline$<0.4$ & 199 & $7 / 16 / 62$ & Long & Foiba wall near \#9-pool \\
\hline$<0.4$ & 116 & $7 / 17 / 62$ & Colossal & Vaughn's Domes-small pool \\
\hline$<0.4$ & 148 & $7 / 17 / 62$ & Colossal & $5.5 \mathrm{~m}$. above main pool \\
\hline$<0.4$ & 139 & $7 / 17 / 62$ & Colossal & Vaughn's Domes-main pool \\
\hline$<0.4$ & 143 & $7 / 17 / 62$ & Colossal & Drain stream-16 m. from \#13 \\
\hline$<0.4$ & 140 & $7 / 17 / 62$ & Colossal & Drain stream-28 m. from \#13 \\
\hline 0.4 & 127 & $7 / 17 / 62$ & Colossal & Colossal Dome-pool \\
\hline 3.2 & 168 & $7 / 18 / 62$ & Mammoth & Charlet's Dome- $5.5 \mathrm{~m}$. above floor \\
\hline 3.8 & 170 & $7 / 18 / 62$ & Mammoth & Charlet's Dome-1.8 m. above floor \\
\hline$\sim 3.6$ & 168 & $7 / 18 / 62$ & Mammoth & Charlet's Dome- $0.5 \mathrm{~m}$. above floor \\
\hline$\sim 0.7$ & 139 & $7 / 19 / 62$ & Great Onyx & Foiba with stairway-pool \\
\hline$\sim 0.4$ & 115 & $7 / 19 / 62$ & Mammoth & Foiba(?) pool in Becky's Alley \\
\hline$\sim 0.4$ & 114 & $7 / 19 / 62$ & Mammoth & $1.7 \mathrm{~m}$. below \# 23 \\
\hline$\sim 0.4$ & 102 & $7 / 19 / 62$ & Mammoth & $\begin{array}{l}\text { Cathedral Domes- } 2.7 \mathrm{~m} \text {. above } \\
\text { pool }\end{array}$ \\
\hline$\sim 0.4$ & 108 & $7 / 19 / 62$ & Mammoth & Cathedral Domes-1 m. above pool \\
\hline$\sim 0.4$ & 106 & $7 / 19 / 62$ & Mammoth & Cathedral Domes-pool \\
\hline$\sim 0.4$ & 91 & $7 / 19 / 62$ & Surface Spring & Flint Ridge-base of Haney Fm. \\
\hline$<1.5$ & 250 & $12 / 15 / 62$ & Saltpeter & Foiba pool \\
\hline$<1.5$ & 275 & $12 / 15 / 62$ & Saltpeter & Spring at cave entrance \\
\hline$<1.5$ & 365 & $12 / 15 / 62$ & Bunch & Stalactite drip \\
\hline$<1.5$ & 295 & $2 / 16 / 63$ & Devil's Icebox & Foiba pool \\
\hline \multirow[t]{7}{*}{$<1.5$} & 270 & $2 / 16 / 63$ & Devil's Icebox & Moonmilk Dome pool \\
\hline & & $8 / 14 / 63$ & $\begin{array}{l}\text { Lower Burnt } \\
\text { Mill }\end{array}$ & Cave pearl pool \\
\hline & & $9 / 6 / 63$ & Hunter's & Cave stream \\
\hline & & $9 / 10 / 63$ & Cox & Foiba pool \\
\hline & & $9 / 10 / 63$ & $\operatorname{Cox}$ & Stalactite \\
\hline & & $9 / 10 / 63$ & Cox & Cave stream \\
\hline & & $9 / 10 / 63$ & Cox & Rimstone dam \\
\hline
\end{tabular}


due to long contact with the high carbon dioxide atmospheres occurring in soils (Hem, 1959, p. 76). This exposure could account for the higher concentrations of principal ions in the Missouri samples. The other Missouri foiba samples, taken during cold conditions, show fairly high concentrations of the principal ions, which probably results from extended contact with the soil. In this case, the soil no doubt contains less carbon dioxide due to low microbial activity, as suggested by Moore (1962).

When foiba waters are compared with more concentrated cavewater samples taken in Missouri from waters depositing speleothems, it can be seen that the foiba waters have had less residence time in the zone of aeration. This evidence lends support to the idea that meteoric water moving quickly through the vadose zone is responsible for foiba development.

\section{Field Evidence}

Foibe develop in diverse geographic and geologic areas in the United States. Three areas will be discussed to show some variations and the unifying similarities displayed by foibe. These areas are: central Kentucky, central and southern Missouri, and south-central Kansas.

The foibe of central Kentucky have been the most extensively studied in the United States. The principal contributors have been Bretz (1942), Brucker (1960, and in preparation), Merrill (1960), Pohl (1955), and Watson (in preparation). A summary of their findings appears in the introduction of this paper. The writer (Reams, 1963a, $1963 \mathrm{~b})$ has emphasized some facts concerning the foibe of this area which have received little attention. The ceilings of foibe in central Kentucky are nearly flat and the longitudinal middle axis is usually grooved by an upside-down, meandering channel along its entire length. Most foibe are noticeably elongated along the longitudinal axis, but are quite narrow at right angles to this axis. The elongation has been considered to be the result of serial coalescence (Pohl, 1955; Merrill, 1960; Brucker, 1960, and in preparation). However, the ceilings are nearly at the same elevation throughout the entire length. Each foiba seems to be one genetic unit, although a type of serial development may have occurred in some cases.

Water usually enters foibe at only one end of the elongated cavity and exits through a small lateral drain or hole in the floor. The wet end of the foiba usually is directed toward the source of water. The Big Clifty Sandstone contains a perched water table which provides a year-round source of water for foibe located below the sandstone outcrop on the 
edges of flat-topped ridges (Philip M. Smith, personal communication, December, 1962). Except for the end where water enters, most foibe are relatively dry.

Merrill (1960, and personal communication, January, 1964) has verified the presence of two or more foibe one on top of another, "hourglass" style, with less soluble chert beds, siliceous coral zones, impure limestones, and dolomite units intervening between them. A less soluble unit thus forms the floor for one foiba and the ceiling of the foiba below it. Floors also form at the water table or may be left above the water table as a result of recent lowering of the zone of saturation.

In order to maintain a vertical-walled waterfall, it is accepted geomorphic theory that a resistant layer is needed. It seems clear that most large central Kentucky foibe are the result of underground waterfalls (used in the broad sense) which begin when seeping water opens a joint below a less soluble layer. This is followed by enlargement and elongation by water dripping from the less soluble layer at the top of the foiba. Water may move vertically through sinkholes until a less soluble layer is reached. Movement would then be lateral, along ceiling channels formed during a prior solutional epoch or as a result of the lateral movement of the water presently under consideration. In either case, the ceiling channels are probably controlled by fractures. Water travels through the channels until fractures in the less soluble layers are reached. The water then proceeds to dissolve the underlying limestone. A less soluble layer becomes an overhanging lip which is undermined in much the same way a Niagara-type waterfall migrates upstream. Some foibe that are not elongated may be fed by water which is not diverted laterally.

Bretz (1942) proposed a somewhat related theory which utilized ceiling channels as paths along which water could travel and form foibe by coring out large blocks and allowing them to fall into a cave passage. There is little evidence that coring is an active process in the development of Kentucky foibe (Pohl, 1955).

The foibe of central and southern Missouri are developed mainly in Mississippian (Lower Carboniferous) limestones, although some form in Ordovician dolomites. The dolomites are capped by a thick resistant sandstone caprock. Chert lenses occur through the limestones and dolomites and form the ceilings, and frequently the floors, of all the foibe that the author has studied. Deike and Deike (1959) noticed that the foibe in a cave in Mississippian limestone in central Missouri possessed chert ceilings. Water is directed onto the lower parts of Missouri foibe by the chert layers so that nearly vertical walls are 
produced (Fig. 5). Foibe in Missouri rarely exceed $25 \mathrm{~m}$. in height and most are not over a few meters high.

Kentucky foibe bear almost no genetic relation to horizontal cave passages and intersect cave levels at randomly distributed points. Foibe in Missouri can be roughly divided into three groups: (1) those which intersect the cave levels predominantly in the ceilings and are associated with ceiling concavities, (2) those which intersect the cave along the side walls, and (3) those which are separated from the main cave passages by long, low, water-filled passages. This grouping is only for the sake of discussion and bears little relationship to any natural, genetic division.

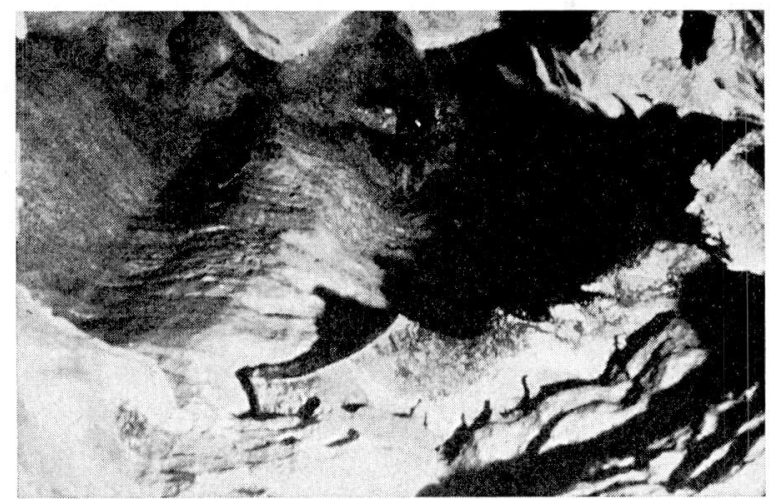

Fig. 5. Looking almost vertically upward into a foiba developed in the ceiling of a Missouri cave. The base of the foiba is about a meter long. Note the chert ceiling and the chert protruding at the base of the cavity. A vertical joint bisects the foiba and chert longitudinally. Water drips through a hole in the upper chert layer into the foiba.

The first group usually seems to form by a combination of phreatic and vadose processes. Fluctuaring water table conditions have probably filled the cave passages with water from time to time, enlarging prominent joints in the cave ceilings. Such easily opened joints were also easy paths for vadose water to percolate down and enlarge cavities to form vertical-walled foibe below chert layers. Joints seem to penetrate the chert layers in most cases. The second group is initiated almost exclusively by enlargement of joints below chert layers and probably have not been effected by a fluctuating water table to such a degree as those foibe in group one. The third group is large (Jerry D. Vineyard, personal communication, August, 1963) and especially interesting. The only difference between these and other Missouri foibe is their inaccessibility. These foibe are no doubt joint 
enlargements below chert layers. The small passages by which the third group is reached are probably the drains of the respective foibe. Brucker (1960, and in preparation) postulated that lateral drains of foibe in central Kentucky, upon lowering of the water table, dried out and became new dendritic cave systems. The validity of this concept for foibe in central Kentucky and Missouri is uncertain and will require extensive field mapping to test its likelihood. The author favors the view that foiba drains are primarily recent additions to the much older cave systems. The formation of Missouri foibe may be considered to be the enlargement of joints under chert layers by dripping and flowing water. The foiba floors are formed by intersection of chert layers or the water table, while some foibe are terminated by intersection of cave passages.

Bretz (1956) postulated a coring theory for foibe in Missouri similar to that suggested for Kentucky foibe (Bretz, 1942). This hypothesis has been replaced (Bretz and Harris, 1961) by a joint-enlargement theory similar to Pohl's (1955) and the theory presented here, but without the importance given to the presence of a less soluble layer.

Foibe in Kansas have only recently been studied (Reams, 1964). These cavities are found in the caves of the two main karst areas of Kansas: (1) the outcrop area of the Fort Riley Limestone (Permian) in south-central Kansas and (2) the outcrop area of the Permian gypsum units $150 \mathrm{~km}$. or more to the southwest. The Fort Riley Limestone is very cavernous and contains caves of several kilometers in length. The unit is not as thick as most karstic limestones, and no foibe could be expected to be higher than the maximum thickness of $15 \mathrm{~m}$. (Moore, et al. 1951, p. 45-46), unless collapse of lower units would allow extension downward. The foibe in the Fort Riley Limestone occur in the center of cave ceilings along the same joints that control the cave passages, which are among the most striking examples of joint control the author has seen. These foibe are very similar to group one of the Missouri foibe. Fort Riley foibe blend into ceiling cavities formed by a fluctuating water table in an even more striking way than do the Missouri foibe. The largest foiba seen by the author in Kansas is about $3.5 \mathrm{~m}$. high. These larger foibe must reach very near the surface because the caves are at shallow depths. Foiba floors are formed by less soluble layers or the cavities intersect cave passages.

The gypsum caves in Kansas are much shorter (usually not over a few hundred meters long) than the limestone caves and are located in a more arid region. Foibe are mainly found developing on the sides of steep, collapse sinkholes leading into the caves and are not necessarily directly joint controlled. They range up to $3.5 \mathrm{~m}$. in height and form 
below minor, less soluble layers in the gypsum (Fig. 6). Their walls, like those of Kansas foibe formed in limestone, are grooved and jagged. These foibe act as small feeders for the intermittent cave streams.

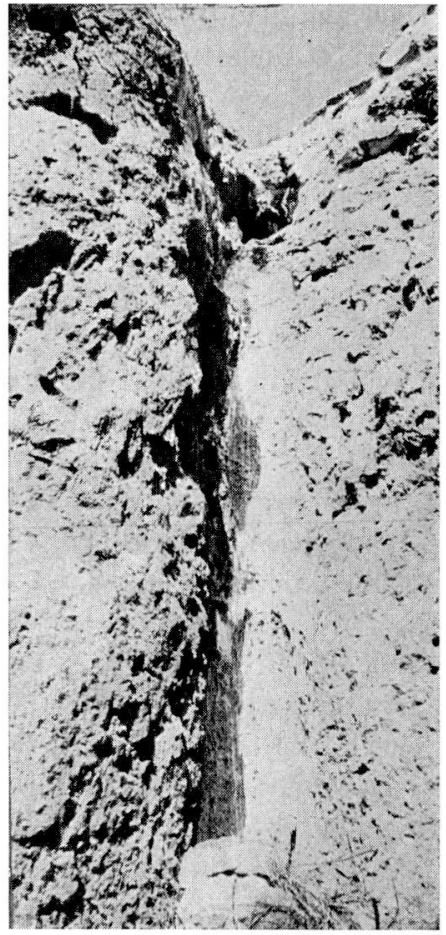

Foiba floors form by intersection with the water table (cave stream), or other less soluble layers.

Dripping water was suggested as a mechanism for foiba development in anhydrite in Mexico by McAllister and Hernandez (1945, p. 62).

\section{Conclusions}

Foibe in various regions seem to display two common features: (1) they have nearly vertical walls and (2) they form below less soluble layers which serve to limit water flow to an area immediately below, and therefore allow dripping and pouring water to plane off the walls, producing

Fig. 6. Foiba forming in the wall of a collapse sinkhole in gypsum. Note the less soluble layer at the top of the foiba. The base is obscured by fallen blocks. The total height of the foiba is about 3.5 meters.

an unusual verticality. The floors are formed by less soluble layers or at the water table, or no floor may exist due to intersection with a cave passage. Experimental laboratory models support this reasoning. The close association of joints bisecting foibe and the joint control of foiba water supplies lend support to joint expansion from near the surface to the water table by vadose water as a most tenable theory.

\section{ACKNOWLEDGEMENTS}

This work was supported by U.S. Atomic Energy Commission Project No. AT (11-1)-1057. The staff of the National Park Service and members of the National Speleological Society and Cave Research Foundation aided materially. Special thanks for helpful discussions, criticisms, and information are due to E.J.Zeller, Wakefield Dort, Jr., H.A. Ireland, E. R.Pohl, J.D.Vineyard, R.W.Brucker, G. K. Merrill, and M.D.Turner. 


\section{ABSTRACT}

Foiba (plural, foibe) is a term derived from the northeastern Italian karst region. The word is here suggested for use in preference to other terms referring to vertical cavities in soluble rocks. Foiba is defined as a cavity in relatively soluble rock which is natural, solutional, tends toward a cylindrical shape, and possesses walls which normally approach verticality.

In laboratory experiments, limestone blocks were treated with dilute hydrochloric acid, and cavities resembling foibe were produced. Vertical walls developed only when a less soluble layer capped the limestone block or when the acid source was stationary, allowing acid to drip to the area directly below.

Water analyses from foibe in central Kentucky and Missouri indicate that the water has had less residence time in the zone of aeration than other waters percolating through the rocks and entering the caves.

In central Kentucky, foibe seem to be developed by migrating underground waterfalls held up by less soluble layers or by water moving directly down joints below less soluble layers. In Missouri, foibe are formed by joint enlargement below chert layers. Those foibe in the ceilings of caves are complicated by the enlargement of the lower part of the joints by cave streams during fluctuating water table conditions. In limestone caves of Kansas, foibe are formed in a similar manner as in Missouri. The foibe of the gypsum caves of Kansas are formed mainly on the sides of steep collapse sinkholes and lack joint control although they form beneath less soluble layers in the gypsum.

Dripping water is necessary for the development of vertical walls by solution. Less soluble layers seem to be the unique feature which allows water to drip and pour into foibe.

The floors of foibe are formed by less soluble layers or near the water table. If foibe intersect previously formed cave passages, no floors may develop.

\section{ZUSAMMENFASSUNG}

Foiba (Mehrzahl, Foibe) ist eine Bezeichnung, die aus dem nordöstlichen Teil des italienischen Karstgebirges stammt. Dieses Wort wird hier anderen Bezeichnungen gegenüber, die sich auf vertikale Löcher in lösbarem Gestein beziehen, bevorzugt. Foiba ist ein Loch in relativ lösbarem Gestein, natürlich durch Lösung geformt und von zylindrischer Gestalt. Es hat Wände, die in natürlicher Weise Vertikalität anstreben.

In Laboratoriumsuntersuchungen wurden Kalksteinblöcke mit verdünnter Salzsäure behandelt und Löcher, die Foibe ähnelten, erzeugt. Vertikale Wände bildeten sich nur, wenn eine weniger lösbare Lage den Kalkstein bedeckte oder wenn die Säurequelle stationär war, so daß die Säure auf die unmittelbar darunterliegende Fläche tröpfeln konnte.

Wasseranalysen aus Foibe in der Zentralgegend von Kentucky und Missouri zeigen, daß das Wasser weniger Zeit in luftdurchwehten Zonen verbrachte als anderes Wasser, welches durch die Felsen sickerte, um in die Höhlen einzudringen.

In der Zentralgegend von Kentucky scheinen Foibe sich mit Hilfe von wandernden unterirdischen Wasserfällen $\mathrm{zu}$ entwickeln, welche durch weniger lösbare Schichten oder durch unmittelbar nach unten über 
Verbindungsstellen aus weniger lösbaren Schichten sich bewegendes Wasser aufgehalten wurden. In Missouri bilden sich Foibe durch Vergrößerung der Grenzschichten unter feuersteinartigem Quarz. Die Foibebildung in den Decken der Höhlen wird durch den unteren Teil der Grenzschicht, die von Höhlenströmen infolge wechselnden Wasserspiegels vergrößert wird, erschwert. In den Kalksteinhöhlen von Kansas bilden sich Foibe ähnlich wie in Missouri. Die Foibe in den Gipshöhlen von Kansas bilden sich hauptsächlich auf den Seiten von steilen, durch den Flüssigkeitsstrom geformten Schächten, die keine Grenzschicht besitzen, obwohl sie sich unter weniger lösbaren Schichten im Gips bilden.

Tropfendes Wasser ist notwendig für die Bildung der vertikalen Wände durch Lösung. Weniger lösbare Schichten scheinen das einzige zu sein, wodurch Wasser auf die Foiba tropft und in die Foiba fließt.

Der Boden der Foiba bildet sich durch weniger lösbare Schichten oder nahe dem Wasserspiegel. Wenn Foibe schon vorher gebildete Höhlengänge durchkreuzt, bilden sich keine Böden.

\section{REFERENCES}

Bretz, J. H. (1942) - Vadose and phreatic features of limestone caverns. Jour. Geol., v. 50:675-811.

- (1956) - Caves of Missouri. Missouri Geol. Survey and Water Resources, v. 39 , 2nd ser. : 490 .

Bretz, J. H., and Harris, S. E., Jr. (1961) - Caves of Illinois. Illinois Geol. Survey Rept. Inv. 215: 88.

Brucker, R. W. (1960) - Relationship of vertical shafts to other cave features (abst.). Natl. Speleol. Soc. News, v. 18, no. 7: 76.

Davies, W. E. (1950) - The caves of Maryland. Maryland Dept. Geol. Mines and Water Resources Bull. 7: 76.

Davis, W. M. (1930) - Origin of limestone caverns. Geol. Soc. America Bull., v. $41: 475-628$.

Deike, R. G., and Deike, G. H. (1959) - Genesis of a ceiling channel in the Devils Icebox, Boone Co. Missouri Speleology, v. 1, no. 4: 1-4.

Hem, J. D. (1959) - Study and interpretation of the chemical characteristics of natural water. U.S. Geol. Survey Water-Supply Paper, 1473:269.

Holland, H. D., Kirsipu, T. V., Huebner, J. S., and Oxburgh, U. M. (1964) - On some aspects of the chemical evolution of cave waters. Jour. Geol., v. 72: 36-67.

Howard, A. D. (1963) - The development of karst features. Natl. Speleol. Soc. Bull., v. $25: 45-65$.

Instituto Geografico Militare (1924) - Foglio 65 B IV, Sud Ovest, Gallignana (map).

Instituto Geografico Militare (1930) - Foglio 55, Giaveno (map).

IreLAND, H. A. (1955) - Surface tension as a factor in gradation. Am. Jour. Sci., v. $253: 162-172$.

Ivanov, B. N., and Dublyansky, V. N. (1959) - Novosti speleologii Kryma: in Gvozdetsky, N. A., ed., Speleolgiya i karstovedenie (Speleology and studies in karst): Moskovskoe obshchestvo ispytatelei Prirody, geograficheskaya Sektsiya, p. 87-93 (with English summary entitled, New discoveries in speleology studies of the Crimea, p. 93). 
Kaye, C. A. (1957) - The effect of solvent motion on limestone solution. Jour. Geol., v. 65 : 35-46.

McAllister, J. F., and Hernandez Ortiz, David (1945) - Quicksilverantimony deposits of Huitzuco, Guerrero, Mexico. U.S. Geol. Survey Bull. 946-B: 71.

Merrill, G. K. (1960) - Additional notes on vertical shafts in limestone caves. Natl. Speleol. Soc. Bull., v. 22: 101-108.

Meunier, Stanislas (1875) - Sur les puits naturels du calcaire grossier. Acad. Sci. Comptes Rendus, v. 80: 797-799.

- (1899) - La géologie experimentale. Paris, Felix Alcan, 311.

Moore, G. W. (1962) - The growth of stalactites. Natl. Speleol. Soc. Bull., v. 24: 95-106.

Moore, R. C., Frye, J. C., Jewett, J. M., Lee, W., and O'Connor, H. G. (1951) - The Kansas rock column. Kansas Geol. Survey Bull. 89:132.

Pонц, E. R. (1955) - Vertical shafts in limestone caves. Natl. Speleol. Soc. Occasional Paper no. 2: 24.

Reams, M. W. (1963a) - A comparison between laboratory models and naturally occurring domepits (abst.). Natl. Speleol. Soc. News, v. 21, no. $2: 17$.

- (1963b) - Some experimental evidence for a vadose origin of foibe (domepits). Unpublished Master's thesis, University of Kansas.

- (1964) - A comparison of limestone and gypsum karst features (abst.). Geol. Soc. America Spec. Paper no. 76: 134-135.

Reams, M. W., and Vineyard, J. D. - In preparation, Annual variations in cave-water chemistry.

St. Vincent, Bory de (1819) - Sur le plateau de St. Pierre, près de Maestricht. Annales Générales des Sciences Physiques, v. 1: 185-273, Bruxelles.

Valla di, A. (1954) - Il Novissimo Melzi, II, Scientifico. XXIV Edizione, Milano, 1364.

Watson, R. A. - In preparation, Observations on vertical shafts in Floyd Collin's Crystal Cave, Kentucky and similar features in Carlsbad Caverns, New Mexico.

- - In preparation, Pitdomes in the Mammoth Cave region.

WEYL, P. K. (1958) - The solution kinetics of calcite. Jour. Geol., v. 66: 163-176. 